УДК 37.011.3-051:159.923

DOI https://doi.org/10.26661/2786-5622-2021-3-20

\title{
КОУЧИНГ ЯК ПРОЦЕС ПІДТРИМКИ ТА РОЗВИТКУ НОВИХ МОДЕЛЕЙ ПОВЕДІНКИ В ОСВІТНЬОМУ СЕРЕДОВИЩІ
}

\author{
Зонов Б. С. \\ аспірант кафедри педагогіки і професійної освіти \\ Вінницький державний педагогічний університет \\ імені Михайла Кочюбинського \\ вул. Острозького, 32, Вінниия, Україна \\ orcid.org/0000-0002-5611-7430 \\ b.s.zonov@gmail.com
}

Ключові слова: коучтехнології, коуч-позииії, коучинг, емоційний інтелект, педагогічний коучинг.
У статті розкрито поняття педагогічного коучингу, що визначають його як різновид технології науково-методичного супроводу, систему андрагогічних принципів і прийомів, які сприяють розвитку потенціалу особистостітагрупилюдей, котрі спільнопрацюють(команди, організації), а також забезпечують максимальне розкриття і дієву реалізацію цього потенціалу. Зауважується, що коучинг у системі вищої освіти України може бути використаний як універсальний інструмент, котрий дає можливість ефективно працювати на суб'єкт-суб'єктному рівні. Розкривається таке поняття, як коучинг-технологія, що базується на демократичному стилі керівництва, заснованому на системному мисленні та певним чином організованій техніці запитань, що в кінцевому підсумку орієнтована на перспективу позитивних змін й оптимізацію виробничих відносин на основі співробітництва та налагодження зворотного зв'язку. Акцентовано увагу на тому, що коучинг - це сфокусований на рішенні, орієнтований на результат систематичний процес співробітництва, внаслідок якого коуч сприяє покращенню виконання завдань, збільшенню життєвого досвіду, самостійному навчанню й особистісному зростанню людей. У статті автор зауважує, що класичний коучинговий процес можна розглядати через декілька поетапних кроків: аналіз (оцінка рівня компетенцій, узгодження особистих цілей i цілей організації, які реалізуються в процесі коучингу, укладення контракту); планування (визначення ключових чинників успіху, підготовка плану розвитку вмінь, узгодження плану дій і моніторинг ефективності результатів); впровадження (супровід від моменту «зараз» до моменту «бажане майбутнє», безпосередні дії, відповідно до довгострокових і короткострокових цілей, визначення пріоритетів); оцінку (систематичне надання зворотного зв' язку, схвалення набутих умінь, а також мотивування до відповідальності і прийняття нових викликів, створення методів самодисципліни студента без підтримки коуча). Для фахівців-коучів коучинг - це планований двосторонній процес, в якому людина розвиває вміння та досягає окреслених компетенцій за допомогою ретельної оцінки, цілеспрямованої практики та регулярного зворотного зв'язку. 


\title{
COACHING AS A PROCESS OF SUPPORT AND NEW MODELS OF BEHAVIOR DEVELOPMENT IN THE EDUCATIONAL ENVIRONMENT
}

\author{
Zonov B. S. \\ Postgraduate Student at the Department of Pedagogy and Vocational Education \\ Mykhailo Kotsyubynsky Vinnytsia State Pedagogical University \\ Ostrozkoho str., 32, Vinnytsia, Ukraine \\ orcid.org/0000-0002-5611-7430 \\ b.s.zonov@gmail.com
}

Key words: coach technology, coach positions, coaching, emotional intelligence, pedagogical coaching.

\begin{abstract}
The article reveals the concept of pedagogical coaching as a kind of technology of scientific and methodological support, a system of andragogical principles and techniques that promote the potential of individuals and groups of people working together (teams, organizations), and ensure maximum disclosure and effective implementation of this potential. It is noted that the use of coaching in the higher education system of Ukraine can be used as a universal tool that allows you to work effectively at the subject-subject level. The concept of coaching technology is based on a democratic leadership style, systematic thinking and a well-organized question technique, which is ultimately focused on the prospect of positive change and optimization of production relations, based on cooperation and feedback. Emphasis is placed on the fact tha $t$ coaching is a decision-focused, result-oriented systematic process of cooperation, during which the coach helps to improve the performance of tasks, increase life experience, self-study and personal growth.

In the article the author notes that the classic coaching process can be considered through several step-by-step steps: analysis (assessment of the level of competencies, coordination of personal goals and goals of the organization, which are implemented in the coaching process, contract); planning (identification of key success factors, preparation of a skills development plan, coordination of an action plan and monitoring of the effectiveness of results); implementation (support from the moment "now" to the moment "desired future", direct actions in accordance with long-term and short-term goals, setting priorities); assessment (systematic provision of feedback, approval of acquired skills, as well as motivation to take responsibility and accept new challenges, creating methods of student self-discipline without the support of a coach). For coaching professionals, coaching is a planned two-way process in which a person develops skills and achieves defined competencies through careful assessment, focused practice, and regular feedback.
\end{abstract}

Постановка проблеми. Провідні фахівці у галузі освіти останніми роками одностайно говорять про глибоку й системну кризу в цій сфері. Експерти світового рівня, аналізуючи теперішнє і майбутнє освітніх процесів, акцентують увагу на необхідності переходу від передавання знань й навичок до розвитку творчих талантів та інноваційного мислення. На практиці це означає перехід від усталених традицій педагогіки до новітньої парадигми коучингу як максимального розкриття потенціалу людини на всіх вікових етапах [5]. А. Цивінська дає визначення коучингу як процесу підтримки, розвитку і закріплення вмінь за допомогою іншої особи - коуча - через спостереження, постановку цілей та завдань, регулярне надання зворотного зв'язку і тренування нових моделей поведінки [8].
Мета статті - розглянути коуч-технології та коучинг як процес підтримки і розвитку нових моделей поведінки в освітньому середовищі.

Виклад основного матеріалу. В сучасну освіту неминуче починають проникати коуч-технології. На відміну від традиційної освіти вони допомагають студентам міркувати, а не бездумно завчати порожні факти. Коучинг у цій сфері характеризується особистісним підходом до кожного здобувача вищої освіти, підтримкою, усвідомленою участю в процесі і досягненні конкретних результатів, виявленням сильних і слабких сторін кожного студента. Найголовніший акцент коучингу у вищій освіті - індивідуальний підхід для підвищення ефективності та результативності в процесі навчання. Своєю чергою коуч-технології передбачають певні вимоги до педагогів: 
дотримання етичних норм, коуч-позиції, відсутність оціночного судження, здатність довести студента до певного результату, вміння слухати і чути його, а також вміння налагоджувати відносини 3 ним, що базуються на довірі та взаєморозумінні. Такі взаємини необхідно підтримувати не лише на початкових етапах, а й упродовж усього періоду навчання. Роль коучингу у вищій освіті полягає в тому, щоб поліпшити якість комунікацій, підвищити результативність конкретного студента, групи і студентства загалом. У педагогічній літературі минулих років дедалі частіше зустрічаємо термін «коучинг», який впевнено перекочував i3 комерційних тренінгових програм в освітній простір. Це зумовлено насамперед необхідністю адаптації вищої освіти до потреб ії споживачів, намаганням зробити освіту привабливою, гнучкою та доступною, забезпечуючи комфортні умови для професійного становлення і розвитку кожної особистості. Однак феномен коучингу полягає не лише в його навчальних можливостях, а також у формуванні соціальної культури саморозвитку та самовдосконалення $[1$, с. 99].

Використання коучингу в системі вищої освіти України є особливо важливим, оскільки наразі сучасний ефективний викладач вищої школи це фахівець, котрий поєднує в собі безліч ролей: консультанта, наставника, тьютора, фасилітатора, коуча, дослідника, мотиватора, аналітика i менеджера інформаційних ресурсів, експерта, проєктувальника навчальних курсів, який обирає зміст навчання, підбирає та розробляє технології навчання й організації навчального процесу тощо. Коучинг у системі вищої освіти України може бути використано як універсальний інструмент, що дає можливість ефективно працювати на суб'єкт-суб'єктному рівні, тобто вміти керувати собою, допомагати іншим у розвитку особистісного потенціалу, у підвищенні особистої ефективності, розвивати ефективні комунікації, будувати конструктивні взаємини з колегами, створювати і розвивати систему вищої освіти, що максимально дієво працює на результат розв’ язання актуальних завдань тощо [7, с. 144].

Основні аспекти сутності коучингу вивчали чимало науковців, а саме: теоретичне підгрунтя досліджували М. Аткінсон, У. Голлві, М. Дауні та інші, ефективність коучингових технологій розглядали С. Канніо, С. Кові, Дж. Уітмортаін, прикладні аспекти використання інструментів коучингу аналізували Л. Марчініак, Т. Столцфиц, А. Цивінська, зокрема в освіті нашої країни - Т. Борова, О. Нежинська, В. Тименко та інші [7, с. 182]. Коучинг - це сфокусований на рішенні, орієнтований на результат систематичний процес співробітництва, під час якого коуч сприяє покращенню виконання завдань, збільшенню життєвого досвіду, самостійному навчанню й особистісному зростанню людей [2, с. 9]. На думку Е. Гранта, коучинг позитивно впливає на розвиток емоційного інтелекту, оскільки покращує здатність розуміти та використовувати емоції конструктивним способом. Дослідник доходить висновку, що ключовим фактором успіху в поліпшенні виконання роботи є добре керівництво, а ключовим фактором успіху в покращанні керівництва є самосвідомість, тобто наявність сильного емоційного інтелекту [3].

Емоційний інтелект (EQ) - це показник нашої здатності до спілкування, вміння усвідомлювати свої емоції та розуміти почуття інших людей. EQ вважається емоційним еквівалентом пізнавального інтелекту (IQ). У своєму сучасному тлумаченні термін «емоційний інтелект» було застосовано в 1990 р. П. Саловеєм (Peter Salovey) та Дж. Д. Майєром (John D. Mayer). Вони говорили про нього як про форму соціального інтелекту, що включає здатність відстежувати власні почуття й емоції, а також почуття та емоції інших людей; розпізнавати їх і застосовувати цю інформацію для керування власним мисленням та діями. Так, найвідомішим наразі тестом вимірювання емоційного інтелекту людини є створений у 2002 р. Тест на емоційний інтелект Майєра-Саловея-Карузо (MSCEIT V2.0). Це стандартизований тест для вимірювання емоційного інтелекту [4]. Коуч-тренери відіграють важливу роль у розвитку людини, а тому виявлення та залучення до гарної й ефективної тренерської практики є життєво важливим для продовження досягнення успіху [9]. Коучинг-технологія базується на демократичному стилі керівництва, заснованому на системному мисленні і певним чином організованій техніці запитань, що в кінцевому підсумку орієнтована на перспективу позитивних змін та оптимізацію виробничих відносин на основі співробітництва i налагодження зворотного зв'язку [3].

Коучинг - це професійні відносини, які допомагають людям досягти видатних результатів у своєму житті, кар'єрі тощо. Коуч дає змогу подолати розрив між тим, де людина перебуває зараз, i тим, де вона хоче бути. У відносинах між клієнтом і коучем використовується широкий спектр поведінкових технік та методів, які допомагають клієнтові досягти визначених цілей, поліпшити його професійні показники і задоволення. Інакше кажучи, коучинг - це робота над собою під керівництвом тренера, який дає змогу розібратися в цілях і способах їх досягнення [6].

Для фахівців-коучів коучинг - це планований двосторонній процес, в якому людина розвиває вміння та досягає окреслених компетенцій за допомогою ретельної оцінки, цілеспрямованої практики та регулярного зворотного зв'язку. Слід відзначити, що класичний коучинговий 
процес можна розглядати через декілька поетапних кроків: аналіз (оцінка рівня компетенцій клієнта, узгодження його особистих цілей і цілей організації, які реалізуються в процесі коучингу, укладення контракту 3 клієнтом); планування (визначення ключових чинників успіху, підготовка плану розвитку вмінь, узгодження плану дій і моніторинг ефективності результатів); впровадження (супровід клієнта від моменту «зараз» до моменту «бажане майбутнє», безпосередні дії, відповідно до довгострокових і короткострокових цілей, визначення пріоритетів); оцінку (систематичне надання зворотного зв'язку, схвалення набутих умінь, а також мотивування клієнта до відповідальності і прийняття нових викликів, створення методів самодисципліни клієнта без підтримки коуча) [7, с. 182].

Навички коуча: емпатія (звичайний член команди ніколи не стане лідером, якщо не здатен співпереживати. Розвиваючи цю навичку, лідери можуть спокійно приймати складні та непопулярні рішення, а їхня команда надасть відповідну підтримку, тому що людина показала себе тією, хто йде до великої мети не лише заради себе, а й заради інших теж); використання відкритих питань (застосування відкритих питань може створити умови для нових рішень, тому що вони змушують подивитися на проблему 3 іншого боку); стратегічне бачення (вміння вибудувати ефективну стратегію розвитку команди і компаніі важливе завдання кожного лідера та коуча); прийняття відповідальності (коучинг включає в себе прийняття відповідальності за результати інших. Інакше кажучи, якщо клієнт досягає успіху - це гарна новина і для коуча. Якщо клієнт не справляється, варто проаналізувати, що можна зробити краще, ефективніше або просто по-іншому) [6].

Педагогічний коучинг (від англ. coaching наставляти, надихати, тренувати для спеціальних цілей, готувати до вирішення певних завдань) - це різновид технології науково-методичного супроводу, система андрагогічних принципів і прийомів, що сприяють розвитку потенціалу особистості та групи людей, котрі спільно працюють (команди, організаціi), а також забезпечують максимальне розкриття й ефективну реалізацію цього потенціалу. Згідно з визначенням Міжнародної федерації коучингу коучинг - це система реалізації спільного соціального, особистісного, творчого потенціалу учасників процесу неперервного розвитку педагогічної майстерності 3 метою отримання максимально можливого результату; співробітництво, яке допомагає клієнтам досягати реальних результатів у своєму особистому і професійному житті.

Основні загальноприйняті значення терміна «педагогічний коучинг» такі: індивідуальне консультування (професійно-фахове, технологічне, психолого-педагогічне, навчально-методичне) для досягнення вищого професійного та особистісного розвитку (акме-рівня); адаптивний стиль управління персоналом, спрямований на неперервний розвиток педагогічної майстерності педагогічного працівника за індивідуальною освітньою траєкторією впродовж усього життя, вміння навчатися і самовдосконалюватися; форма індивідуального та групового консультування для проєкт-менеджерів і керівних працівників середнього i/або вищого рівнів [8, с. 13].

Висновки. Таким чином, коучинг - це планований двосторонній процес, в якому людина розвиває вміння та досягає окреслених компетенцій за допомогою ретельної оцінки, цілеспрямованої практики та регулярного зворотного зв'язку. Визнано, що найголовніший акцент коучингу у вищій освіті - індивідуальний підхід для підвищення ефективності та результативності в процесі навчання.

Роль коучингу у вищій освіті полягає в тому, щоб поліпшити якість комунікацій, підвищити результативність конкретного студента, групи i студентства загалом. Педагогічний коучинг розглядають як різновид технології науково-методичного супроводу, систему андрагогічних принципів i прийомів, що сприяють розвитку потенціалу особистості та групи людей, які спільно працюють (команди, організаціi), а також забезпечують максимальне розкриття й ефективну реалізацію цього потенціалу. Феномен коучингу полягає також не лише в його навчальних можливостях, а й у формуванні соціальної культури саморозвитку та самовдосконалення.

\section{ЛІТЕРАТУРА}

1. Горук Н. Коучинг як ефективна технологія формування самоосвітньої компетентності студентів. Проблеми підготовки сучасного вчителя. 2015. № 11. С. 99-104.

2. Грант Э. Коучинг принятия решений / Э. Грант, Дж. Грин. Санкт-Петербург : Питер, 2005. 138 с.

3. Гурієвська В. Коучинг як прикладна технологія державного управління. Вісник Національної академії державного управління. URL: http://visnyk.academy.gov.ua/wp-content/uploads/2013/11/ 2011-1-6.pdf.

4. Емоційний інтелект i можливості його розвитку. 2016. URL: https://www.empatia.pro/ emotsijnyj-intelekt-i-shlyahy-jogo-rozvy/.

5. Коучинг в освіті: від реформ до еволюції. URL: https://www.facebook.com/events.

6. Леонова Е. Что такое коучинг (и зачем он нужен) URL: https://blog.hurma.work/chto-takoe-kouching/. 
7. Нежинська О. Коучинг як інструмент соціально-психологічної допомоги клієнту. Науковий часопис Національного педагогічного університету ім. М.П. Драгоманова. Серія 11: "Соціальна робота. Соціальна педагогіка» : зб. наук. праць. Київ : Видавництво НПУ ім. М.П. Драгоманова, 2017. Вип. 23. С. 182-187. URL: http://enpuir.npu.edu.ua/handle/123456789/19349.

8. Сидоренко В. Педагогічний коучинг як інноваційна технологія науково-методичного супроводу професійно-особистісного розвитку вчителя в системі післядипломної освіти. Наукова скарбниия освіти Донеччини. Донецьк. 2014. № 3 (14). С. 13-19.

9. Coaching pedagogy and practice. URL: https://www.worcester.ac.uk/about/academic-schools/school-ofsport-and-exercise-science/sport-and-exercise-science-research/coaching-pedagogy-and-practice.aspx.

\section{REFERENCES}

1. Goruk N. (2015) Kouchy'ng yak efekty'vna texnologiya formuvannya samoosvitn'oyi kompetentnosti studentiv [Coaching as an effective technology for the formation of self-educational competence of students]. Problemy pidgotovky suchasnogo vchytelya. № 11. S. 99-104.

2. Grant Je. (2005) Kouching prinjatija reshenij [Decision Coaching] / Je. Grant, Dzh. Grin. SPb. : Piter, 138 s.

3. Guriyevska Valentyna (2013) Kouchyng yak prykladna texnologiya derzhavnogo upravlinnya [Coaching as an applied technology of public administration]. Visnyk Nacionalnoyi akademiyi derzhavnogo upravlinnya. URL: http://visnyk.academy.gov.ua/wp-content/uploads/2013/11/2011-1-6.pdf.

4. Emocijnyj intelekt i mozhlyvosti jogo rozvytku [Emotional intelligence and opportunities for its development]. 2016. URL: https://www.empatia.pro/emotsijnyj-intelekt-i-shlyahy-jogo-rozvy/.

5. Kouchyng v osviti: vid reform do evolyuciyi [Coaching in education: from reforms to evolution]. URL: https://www.facebook.com/events.

6. Leonova E. Chto takoe kouching (i zachem on nuzhen) [What is coaching (and why is it needed)]. URL: https://blog.hurma.work/chto-takoe-kouching/.

7. Nezhynska O. (2017) Kouchyng yak instrument socialno-psyxologichnoyi dopomogy kliyentu [Coaching as a tool of social and psychological assistance to the client]. Naukovyj chasopys Nacionalnogo pedagogichnogo universytetu im. M.P. Dragomanova. Seriya 11: "Socialna robota. Socialna pedagogika" : zb. nauk. pracz. Kyiv : Vyd-vo NPU im. M.P. Dragomanova. Vyp. 23. S. 182-187. URL: http://enpuir.npu. edu.ua/handle/123456789/19349.

8. Sydorenko V. (2014) Pedagogichnyj kouchyng yak innovacijna texnologiya naukovo-metodychnogo suprovodu profesijno-osobystisnogo rozvytku vchytelya $\mathrm{v}$ systemi pislyadyplomnoyi osvity [Pedagogical coaching as an innovative technology of scientific and methodological support of professional and personal development of a teacher in the system of postgraduate education]. Naukova skarbnycya osvity Donechchyny. Doneczk. 2014. № 3 (14). S. 13-19.

9. Coaching pedagogy and practice (2021). URL: https://www.worcester.ac.uk/about/academic-schools/ school-of-sport-and-exercise-science/sport-and-exercise-science-research/coaching-pedagogy-and-practice.aspx. 